\title{
Effect of Different Progeny Test Strategies in the Performance of Eucalypt Clones
}

\author{
By I. V. Furtini ${ }^{1)}$, M. A. P. RAMAlho ${ }^{2)}$, J. I. M. ABAD $^{3)}$ and A. M. AguiaR ${ }^{4}$
}

(Received $15^{\text {th }}$ August 2011)

\begin{abstract}
The objective of the present study was to investigate whether the performance of an individual in clonal testing was affected by the location of the initial selection. The study also evaluated the effect of mass selection and BLUP (Best Linear Unbiased Prediction) on the performance of individuals in the progeny test and the clonal test. In the progeny test, 62 half-sib $E$. grandis families, 68 half-sib $E$. urophylla families and 62 full-sib families between $E$. grandis and $E$. urophylla, plus four checks were evaluated totaling 196 treatments. The experiments were carried out at three sites: Aracruz and São Mateus, in Espírito Santo State and Caravelas, Bahia State, Brazil. The 1000 best individuals were classified by mass selection and BLUP. In the clonal tests 257 clones were evaluated in two locations: Aracruz and Caravelas. In both the progeny test and the clonal test, two years after planting, the circumference at breast height and basic wood density were measured and the sum of standardized variables (Z) was estimated for simultaneous selection of both characteristics. The results indicated that the origin of the individual in a progeny test had a small effect on the performance of the clone when evaluated in other environments; the estimates of realized heritability and the linear regression coefficient were small in all the selection strategies. Thus, the correlation between the performance of trees selected in progeny tests and their respective clones in the clonal test was small.
\end{abstract}

Key words: Plant breeding, selection strategies, realized heritability, Eucalyptus.

\section{Introduction}

At the beginning of the eucalyptus breeding programs, the breeding strategies were based on introductions of individuals of different origins and different species followed by the identification of those most adapted to the Brazilian environmental and mass selection for superior individuals and on half-sib family selection targeting improved seed production. In a second phase, priority was given to cloning rather than sexual methods of seedling production. Researchers began to select superior trees, especially in commercial plantations, most of

\footnotetext{
1) Corresponding author: ISABELA VOLPI FURTINI. Empresa Brasileira de Pesquisa Agropecuária. Rodovia MT 222, km 2,5. CEP 78550-970/Sinop, MT, Brasil. Phone: + 556632114220 , Fax: +55 66 32114220. E-mail: isafurtini@yahoo.com.br

2) Departamento de Biologia, Universidade Federal de Lavras, Caixa Postal 3037, CEP 37200-000/Lavras, MG, Brasil.

3) Fibria Celulose S. A./Centro de Tecnologia, Rod. Aracruz, s/n, Barra do Riacho. CEP 29197-551/Aracruz - ES, Brasil.

4) Fibria Celulose S.A./Centro de Tecnologia, Rod. Gen. Euryale de Jesus Zerbine/Km 84. CEP 12340-010/Jacareí - SP, Brasil.
}

which, it seems, were natural hybrids involving $E$. grandis and E. urophylla (FERREIRA and SANTOS, 1997; REZENDE, 2001).

Significant progress was achieved when it was observed that, to obtain additional gains, superior individuals should be crossed to obtain new genotype combinations (GONÇALVES et al., 2001). Therefore companies with breeding programs intensified hybridization and conducted programs with half-sib and full-sib family selection. More elaborate statistical procedures began to be used to improve selection efficiency with the implementation of computational facilities. One such method is based on the use of mixed model analysis, especially the Best Linear Unbiased Prediction method (BLUP).

In eucalyptus cropping, some studies have compared the efficiency of some selection strategies (RESENDE, 2002; Freitas et al., 2009; Rosado et al., 2009). The superiority of combined selection and BLUP over mass selection and selection among and within half-sib progenies was theoretically demonstrated (RESENDE, 2002). In the field, all the selection strategies were effective in eucalypt breeding (FREITAS et al., 2009). However, no reports were found in the literature comparing the effectiveness of these strategies in future performance of the clones, i.e, the correlation between the performance of a selected individual in a progeny test and its performance in the clonal test. This information is essential for plant breeders to identify the best strategies for selection.

The objective of the present study was to verify whether the location of origin of the individual selected in the progeny test affected its performance in the clonal test. The study also evaluated the effectiveness of different individual selection strategies in the progeny test and its performance in the clonal test.

\section{Materials and Methods}

\section{Progeny Test}

The experiments were carried out in three areas of the company Fibria Celulose S. A., in Aracruz, ES, Brazil: $19^{\circ} 50^{\prime}$ lat S and $40^{\circ} 12^{\prime}$ long W, São Mateus, ES, Brazil: $18^{\circ} 36^{\prime}$ lat $\mathrm{S}$ and $40^{\circ} 01^{\prime}$ long $\mathrm{W}$ and Caravelas, BA, Brazil: $17^{\circ} 47^{\prime}$ lat $\mathrm{S}$ and $39^{\circ} 33^{\prime}$ long W.

In experiments set up between October and November 2001, 62 half-sib $E$. grandis families, 68 half-sib $E$. urophylla families and 62 full-sib families between $E$. grandis and E. urophylla, plus four checks were assessed, totaling 196 treatments. The experimental design was a 14 x 14 lattice design with 40 replications of single tree plots. The plants were spaced at $3 \times 3 \mathrm{~m}$ and the usual management for commercial crops was used. 
Two years after planting, the data were obtained for circumference at breast height and pilodyn needle penetration in the wood $(\mathrm{mm})$. Based on the pilodyn evaluation, the basic wood density $\left(\mathrm{kg} . \mathrm{m}^{-3}\right)$ was estimated by the expression: Density $=615-11^{*}$ Pilodyn reading. To establish this expression, 142 two-year-old trees of different eucalypt species were evaluated previously with the pilodyn and the wood density had been determined in the laboratory. The regression equation between the pilodyn reading and the basic wood density was constructed from these evaluations.

To obtain information on the two traits simultaneously, the data were standardized and the index of the sum of standardized variables ( $Z$ ) was obtained (MENDES et al., 2009). Because the $Z$ variable can assume both positive and negative values, a constant value of four was added to make all the values positive. In this case, the population mean of each trait, instead of zero assumed the constant value.

The progeny test data were analyzed by the restricted maximum likelihood/best linear unbiased prediction (REML/BLUP) procedure, using the SELEGEN computer program (RESENDE, 2007). Analyses were performed according to the following statistical model: $y=X \beta+W p+Z \gamma+\varepsilon$, where $y$ : vector of phenotypic data; $\beta$ : vector of fixed effects of replication and blocks/replication added to the general mean; $p$ : vector of fixed effects of progeny type ( $E$. urophylla and $E$. grandis half-sib families and full-sib families between $E$. grandis x $E$. urophylla); $\gamma$ : vector of genetic effects of individual trees, assumed to be random: $\gamma \sim(\emptyset, \mathrm{G})$; with

$$
G=\bigoplus_{k=1}^{3} I_{k} \sigma_{g_{k}}^{2}(\varnothing, \mathrm{G})
$$

$\oplus$ indicates the operation of direct matrix sum of matrices; $I$ is the identity matrix and $\sigma_{g_{k}}^{2}$ the variance component associated with individual genetic effects. For halfsib progenies, $\sigma_{g}^{2}$ is the individual additive genetic variance and for full-sib progenies $\sigma_{g}^{2}$ is the individual genotypic variance); $\varepsilon$ : vector of errors: $\varepsilon \sim N$. The capital letters represent the incidence matrices for these effects.

The coincidence index was estimated to assess the correlation between the performance of the trees selected by mass selection and BLUP, ignoring the random effects (HAMBLIN and ZiMMERMANN, 1986).

\section{Clonal Test}

The experiments were evaluated in two areas of the company Fibria Celulose S. A., in Aracruz, ES, Brazil: $19^{\circ} 50^{\prime}$ lat $\mathrm{S}$ and $40^{\circ} 12^{\prime}$ long $\mathrm{W}$ and Caravelas, BA, Brazil: $17^{\circ} 47^{\prime}$ lat $\mathrm{S}$ and $39^{\circ} 33^{\prime}$ long $\mathrm{W}$.

To set up the clonal tests, 257 trees were cloned from the progeny test experiments described previously. Table 1 shows the origin of these clones. The experiments were set up between August and September 2007 in a randomized block design with 30 replications of single tree plots. The between plant spacing and experiment management were the same as in the progeny tests. The same traits as in the progeny tests were assessed when the trees were two years old.

The analysis was carried out using the least squares method (LSM) and restricted maximum likelihood / best
Table 1. - Number of clones in the clonal test from the $E$. grandis and E. Urophylla half sib families and E. grandis x E. Urophylla full sib families of progeny tests evaluated in Aracruz, Caravelas and São Mateus.

\begin{tabular}{lccccc}
\hline \multirow{2}{*}{ Type of families } & \multicolumn{4}{c}{ Origin } & \multirow{2}{*}{ Total } \\
\cline { 2 - 5 } & Aracruz & Caravelas & S. Mateus & \\
\hline E. grandis & 6 & 4 & 9 & 19 \\
E. urophylla & 9 & 1 & 16 & 26 \\
E. grandis x E. urophylla & 65 & 51 & 96 & 212 \\
\hline
\end{tabular}

linear unbiased prediction procedures (REML/BLUP). The analysis of variance by location and joint analysis of variance were performed using the Procedure for General Linear Models (PROC GLM) of the $\mathrm{SAS}^{\circledR}$ statistical software (SAS INSTITUTE, 2002).

For the REML/BLUP mixed model analysis, the SELEGEN computer program was used (RESENDE, 2007), which predicted the individual genotypic values. Analyses by location were performed according to the following statistical model: $y=W r+Z g+\varepsilon$, where $y$ : vector of phenotypic data; $r$ is the vector of fixed effects of the replication added to the general mean; $g$ : is the vector of individual genotype effects, assumed to be random: $g \sim N\left(0, G=I \sigma_{g}^{2}\right)$ ( $I$ denotes the identity matrix and $\sigma_{g}^{2}$ the variance component associated with individual genetic effects) and $\varepsilon$ : is the vector of errors: $\varepsilon \sim N\left(0, R=I \sigma_{e}^{2}\right)\left(\sigma_{e}^{2}\right.$ : environmental variance).

The joint analysis was performed according to the following statistical model: $y=X r+Z g+W i+\varepsilon$, where $y$ : vector of phenotypic data; $r$ is the vector of fixed effects of location-replication combination added to the general mean; $g$ : is the vector of individual genotype effects, assumed to be random: $g \sim N\left(0, G=I \sigma_{g}^{2}\right.$ ) ( $I$ denotes the identity matrix e $\sigma_{g}^{2}$ : the variance component associated with individual genetic effects); $i$ : is the vector of the genotype x environment random effects: $i \sim N\left(0, L=I \sigma^{2}{ }_{i}\right)$ ( $\sigma^{2}{ }_{i}$ genotype $\mathrm{x}$ environment variance) and $\varepsilon$ : is the vector of errors: $\varepsilon \sim N\left(0, R=I \sigma_{e}^{2}\right)\left(\sigma^{2} e_{e}\right.$ : environmental variance). The capital letters represent the incidence matrices for these purposes.

The realized heritability $\left(\mathrm{h}_{\mathrm{R}}^{2}\right)$ from mass and BLUP selection were estimated using different selection intensities: 5, 10, 15, 20 and $25 \%$, according to the following estimator (adapted from FEHR, 1987):

$$
h_{R}^{2}=\frac{\left(M s_{j}-M o_{j}\right) / M o_{j}}{\left(M s_{i}-M o_{i}\right) / M o_{i}}
$$

where:

$M o_{i}$ : original mean of the progeny test population; $M s_{i}$ : mean of selected individuals in the progeny test; $M o_{j}$ : original mean of the clonal test; $M s_{j}$ : mean of the individuals in the clonal test, corresponding to the selected individuals in the progeny test.

As the progeny and clonal tests were conducted in different environments, the standardized heritability was also estimated in standard deviation units (Z) (FREY and HoRNER, 1957) and then the heritability was estimated 
by the parent/offspring regression, that is, the regression of the performance of the trees in the progeny test (x) and clonal test (y).

The genetic and phenotypic parameters were estimated from the expected mean square values according to the literature (BERNARDO, 2002).

\section{Results}

\section{Progeny Test}

Significant differences were found in the three traits considered among the progeny $(\mathrm{P}<0.01)$. Its decomposition showed variability among the $E$. grandis and $E$. urophylla half-sib progeny and E. grandis x E. urophylla full-sib progenies.

The coincidence between the trees classified by mass selection and BLUP, for Z, was $68.2 \%$ in Aracruz, $63.3 \%$ in São Mateus and $68.7 \%$ in Caravelas (Table 2).

Table 2. - Estimates of the coincidence index (CI, \%) of the plants selected by mass selection and BLUP and selection gains (\%) considering the two strategies, for the sum of $Z(Z)$ in Eucalyptus progeny tests.

Locations

$\mathrm{CI}$

\section{Aracruz}

68.2

São Mateus

63.2

Caravclas

68.7

Table 3. - Joint analysis of variance for circumference at breast height $(\mathrm{CBH}, \mathrm{cm})$, wood density (WD, $\mathrm{kg} \mathrm{m}^{-3}$ ) and the sum of Z (Z), obtained in the evaluation of two-year-old clones of $E$. grandis, E. urophylla and E. grandis $\mathrm{x} E$. urophylla.

\begin{tabular}{|c|c|c|c|c|}
\hline \multirow{2}{*}{$\begin{array}{l}\text { Source of } \\
\text { variation }\end{array}$} & \multirow{2}{*}{ DF } & \multicolumn{3}{|c|}{ Mean square } \\
\hline & & $\mathrm{CBH}$ & WD & $Z$ \\
\hline $\begin{array}{l}\text { Replications / } \\
\text { locations }\end{array}$ & 58 & $391.48^{* *}$ & $69821.15^{* *}$ & $0.28^{\text {tl.s. }}$ \\
\hline Locations (L) & 1 & $29754.36^{* *}$ & $328.41^{\text {n.s. }}$ & $2.84^{\mathrm{n} .5 \mathrm{~s}}$ \\
\hline Clones (C) & 256 & $392.86^{* *}$ & $17084.93^{\text {** }}$ & $29.76^{* * *}$ \\
\hline Origins $(\mathrm{O})$ & 2 & $232.32^{* *}$ & $61001.66^{* *}$ & $52.69^{* *}$ \\
\hline $\mathrm{AR}^{1}$ & 79 & $396.38^{* *}$ & $17956.00^{* *}$ & $39.47^{* *}$ \\
\hline $\mathrm{CA}^{1 /}$ & 55 & $345.12^{* *}$ & $12829.00^{* *}$ & $27.49^{* *}$ \\
\hline $\mathrm{SM}^{1 /}$ & 120 & $415.78^{* *}$ & $17904.00^{* *}$ & $24.21^{* *}$ \\
\hline $\mathrm{C} \times \mathrm{L}$ & 256 & $168.94^{* *}$ & $1115.59^{* *}$ & $8.52^{* *}$ \\
\hline $\mathrm{O} \times \mathrm{L}$ & 2 & $563.60^{* *}$ & $3357.33^{* *}$ & $23.77^{* * *}$ \\
\hline AR $\times L$ & 79 & $166.86^{* *}$ & $1061.54^{* *}$ & $8.59^{* *}$ \\
\hline$C A \times L$ & 55 & $165.94^{* *}$ & $968.79^{* *}$ & $7.02^{* *}$ \\
\hline $\mathrm{SM} \times \mathrm{L}$ & 120 & $164.27^{* *}$ & $1177.34^{* *}$ & $8.88^{* *}$ \\
\hline Erro & 12897 & 14.10 & 339.17 & 1.15 \\
\hline Accuracy $(\%)$ & & 76 & 97 & 84 \\
\hline Mcan clonc & & 36.68 & 434.23 & 7.95 \\
\hline Mean AR & & 36.20 & 434.37 & 7.92 \\
\hline Mean CA & & 36.71 & 428.95 & 7.79 \\
\hline Mean SM & & 36.29 & 436.96 & 8.03 \\
\hline
\end{tabular}

${ }^{1 /} \mathrm{AR}$ - selected clones in Aracruz, ES; CA - selected clones in Caravelas, BA e SM - selected clones in São Mateus, ES.

** -Significant at $1 \%$ probability by F test; n.s - not significant.

\section{Clonal Test}

The ten best clones were identified similarly in the comparison of the LSM and REML/BLUP analyses (data not shown). As the two procedures provided similar classification, the presentation of the results will refer to the LSM analysis.

Table 3 shows the analyses of variance of the 257 clones. The accuracy estimates indicated good experimental precision. For all traits, the estimated accuracy values were above $75 \%$. Significant differences $(\mathrm{P}<0.01)$ occurred among locations for circumference at breast height $(\mathrm{CBH})$ (Table 3). The highest estimates were obtained in Aracruz, where the average $(37.9 \mathrm{~cm})$ was $8 \%$ higher than that obtained in Caravelas $(34.8 \mathrm{~cm})$ (data not shown). Significant differences $(\mathrm{P}<0.01)$ were detected among the clones for all the traits. Taking origin as source of variation, significant differences were observed for the three traits $(\mathrm{P}<0.01)$ (Table 3). Considering $\mathrm{Z}$, it was observed that clones from plants evaluated at São Mateus performed better but the difference was not significant. In principle, this result shows that the selection location of the tree did not significantly affect the clone performance in other conditions. The source of variation origin $\mathrm{x}$ location was significant $(\mathrm{P}<0.01)$. The same applied to the interactions involving clones of each origin $\mathrm{x}$ locations, indicating at first that the clone performance was not coincident at the two locations (Table 3). Estimates of genetic correlation $\left(\hat{r}_{g}\right)$ between the average clone performance of clones in the two locations highlights this observation. For example, in the case of $\mathrm{Z}$, the $\left(\hat{r}_{g}\right)$ was only 0.58 (Table 4 ). Because there were significant interactions, results will be focused on the clone performance per site.

Estimates of broad sense heritability $\left(\mathrm{h}^{2}\right)$ on the clone mean in Aracruz and Caravelas were above $93 \%$ and the confidence interval showed that they were different from zero at $95 \%$ probability (Table 4 ).

Table 5 shows the realized heritability $\left(\mathrm{h}_{\mathrm{R}}^{2}\right)$ estimates for $\mathrm{Z}$, considering the two selections and different tree

Table 4. - Heritability estimates on clone mean $\left(h^{2}{ }_{m c}, \%\right)$ in Aracruz, Caravelas and joint of two locations, genetic correlation $\left(\hat{r}_{g}\right)$ between the mean clone performance in two locations, for circumference at breast height $(\mathrm{CBH}, \mathrm{cm})$, wood density (WD, $\mathrm{kg} \mathrm{m}^{-3}$ ) and sum $\mathrm{Z}(\mathrm{Z})$, obtained in the evaluation of Eucalyptus clones.

\begin{tabular}{|c|c|c|c|}
\hline \multirow{2}{*}{ Parameters } & \multicolumn{3}{|c|}{$\mathrm{CBH}$} \\
\hline & Aracruz & Caravelas & Joint \\
\hline$h_{m c}^{2}$ & $\begin{array}{c}95.5 \\
(94.7-96.2)^{1 /}\end{array}$ & $\begin{array}{c}94.5 \\
(93.6-95.4)\end{array}$ & $\begin{array}{c}56.9 \\
(44.8-66.4)\end{array}$ \\
\hline \multirow[t]{3}{*}{$\hat{r}_{g}$} & - & - & 0.42 \\
\hline & \multicolumn{3}{|c|}{ WD } \\
\hline & Aracruz & Caravelas & Joint \\
\hline$h_{m c}^{2}$ & $\begin{array}{c}0.964 \\
(95.9-96.9)\end{array}$ & $\begin{array}{c}0.962 \\
(95.5-96.9)\end{array}$ & $\begin{array}{c}93.5 \\
(91.6-94.8)\end{array}$ \\
\hline \multirow[t]{3}{*}{$\hat{r}_{g}$} & - & - & 0.91 \\
\hline & \multicolumn{3}{|c|}{$Z$} \\
\hline & Aracruz & Caravelas & Joint \\
\hline$h_{m c}^{2}$ & $\begin{array}{c}94.4 \\
(93.4-95.2)\end{array}$ & $\begin{array}{c}93.5 \\
(92.4-94.6)\end{array}$ & $\begin{array}{c}71.4 \\
(63.3-77.6)\end{array}$ \\
\hline$\hat{r}_{g}$ & - & - & 0.58 \\
\hline
\end{tabular}

1/ Values in parentheses refer to the upper and lower limits of confidence intervals, at $5 \%$ probability. 
Table 5. - Estimates of realized heritability at different selection intensities in a clonal test and linear regression coefficient (b) between the tree performance in progeny tests and Eucalyptus clonal tests for the sum of Z (Z), in Aracruz and Caravelas.

\begin{tabular}{ccccccc}
\hline & \multicolumn{5}{c}{ Mass selection } \\
\cline { 2 - 6 } Locations & \multirow{2}{*}{$\mathrm{b}$} & $5 \%$ alized heritability \\
\cline { 3 - 7 } & & $50 \%$ & $15 \%$ & $20 \%$ & $25 \%$ \\
\hline Aracru\% & $0.370^{* * *}$ & 0.002 & 0.069 & 0.181 & 0.234 & 0.301 \\
Caravelas & $0.302^{* *}$ & -0.090 & 0.061 & 0.161 & 0.180 & 0.248 \\
\hline & & \multicolumn{5}{c}{ BLUP } \\
\hline Aracruz & $0.301^{* *}$ & -0.030 & -0.070 & -0.060 & 0.024 & 0.095 \\
Caravelas & $0.245^{* *}$ & -0.119 & -0.072 & -0.069 & 0.090 & 0.190 \\
\hline
\end{tabular}

** Significant at $1 \%$ probability.

selection intensities in the progeny tests. All the $\left(\mathrm{h}^{2}{ }_{\mathrm{R}}\right)$ estimates were of low magnitude in all the locations and increased with the increase in the number of clones selected, i.e, with decrease in selection intensity but even so, these values were very close to zero.

The linear regression coefficient (b) estimates were similar for $\mathrm{Z}$ in the two selections evaluated (Table 5). In two locations, the mass selection and BLUP estimates differed from zero, but although the estimates were significant, their magnitudes were low.

\section{Discussion}

Normally, breeders handle several traits at the same time. The present study, for example, involved a tree growth trait and a wood quality trait. In this situation, simultaneous selection for traits is more efficient with a selection index. There are many selection indexes in the literature (BERNARDO, 2002). The index obtained by the sum of standardized variables $(\mathrm{Z})$ is easy to estimate and interpret (MENDES et al., 2009). Furthermore, with standardized variables, the data can be compared in any situation. Therefore, discussions will be focused mainly on the sum of Z, which represents the breeder's objective.

The coincidence between the individuals selected by mass selection and BLUP was not high (Table 2). It could be inferred that mass selection was less efficient compared with BLUP. Although the same individual/progeny may not be identified by two or more selection strategies, individuals very similar in performance are identified.

In plant breeding, mixed model analysis by BLUP has frequently been used (RESENDE, 2002; NuNES et al., 2008; PIEPHO et al., 2008). The analysis by LSM and BLUP provided similar results when there was no data loss (BERNARDO, 2002). It is practically impossible to have balanced experiments where the plot consists of a single plant, mainly in respect to forest genetic breeding. The question is, at what level of imbalance would BLUP be most advisable. In the present study, $14 \%$ of the trees were lost in Aracruz and $11 \%$ in Caravelas and there was no advantage of BLUP over the LSM. Similar results were obtained by comparing eucalyptus clone classification by the mixed model and LSM procedures (SCARPINATI et al., 2009).

Currently, the use of the single plant plot has increased in forest genetic breeeding experiments. This strategy results in greater experimental precision due to higher number of replications (RESENDE, 2007). The estimated accuracy values were above $75 \%$, indicating that the experimental accuracy was high to very high (RESENDE and DuARTE, 2007).

In experiments of this kind it is essential that genetic variation/variability occurs among clones. The clones assessed were derived from $E$. grandis and $E$. urophylla half-sib progenies and $E$. grandis x $E$. urophylla full-sib progenies. Thus, it was expected that they would differ for the three traits, as in fact occurred. Most clones were from $E$. grandis x $E$. urophylla full-sib progenies (Table 1 ). The superiority of the $E$. grandis x $E$. urophylla hybrids in meeting the demands of the pulp industry has been reported on several occasions due to their vigorous growth and good wood quality (BERTOLUCCI et al., 1995; Assis, 2000; REZENDE and RESENDE, 2000; VERRYN, 2000; Bouvet and Vigneron, 2009). Therefore, hybrids between these two species have been used commercially in several countries, including Brazil, South Africa, Colombia, Venezuela and the Congo (RESEnde, 2002).

One objective of the present study was to verify whether the origin of location of the selected individuals in a progeny test affected its performance when evaluated in other conditions. Although the origin as source of variation was significant $(\mathrm{P}<0.01)$, this effect was small (Table 3). In principle, these results showed that the progeny tests need not be conducted in a large number of environments. Unfortunately there are no reports in the literature, in the case of eucalyptus, on the influence of the progeny origin on clone performance in various environments.

One focus of the present study was to assess the selection efficiency of the progeny test in the clone performance in other environmental conditions. The study also assessed whether the selection strategy for the tree that will create the clone has different efficiency, considering the performance of the cloned individual. This efficiency can be compared by several procedures. One is the realized heritability or gain realized with the selection, i.e, the expected gain is estimated with selection of individuals in the progeny test and gain realized from the clone in the clonal test.

Another way to evaluate the selection efficiency is by the parent/offspring regression (HALLAUER et al., 2010). As the progeny and clonal tests were conducted in different environments (years and locations), the tree performance regression was estimated in the progeny test $(\mathrm{x})$ and clonal test (y), using standardized data in standard deviation units (FREY and HoRNER, 1957).

The heritability estimates for realized gain $\left(\mathrm{h}^{2}{ }_{\mathrm{R}}\right)$ and the linear regression coefficient (b) were of low magnitude and provided similar interpretations, regardless of the selection method applied to the progeny test (Table 5 ). One hypothesis to explain the low heritability estimates obtained is the occurrence of the genotype $x$ year interaction. Unfortunately, there are few reports of the occurrence of such interaction in eucalyptus cropping in Brazil. In the few studies found the genetic correlations between the performance of the tree in the progeny test and the clone derived from it were very low. In the aver- 
age of different selection intensity, was only $27 \%$ (REIS et al., 2011). The authors comment that the low estimate of the genetic association between the elite trees and clone performance should be attributed to the interaction of genotypes $\mathrm{x}$ years.

Although the BLUP is the best predictor of the genotypic value, its efficiency in responding to selection in subsequent years was not different from mass selection, because it cannot predict the future effect of the genotype $\mathrm{x}$ year interaction. Thus, selection success always depends on the most accurate evaluation of the progenies and the use of alternatives to reduce the genotype $x$ year effect. Thus, to reduce the effect of this interaction, the option would be to use a lower selection intensity on the trees in a progeny test, in order to increase the possibility of identifying clones with improved performance.

\section{Conclusions}

The origin of the individual in the progeny test had a small effect on the clonal performance when evaluated in other locations.

Estimates of realized heritability and the linear regression coefficient in the two selection strategies used were small. That is, the correlation was low in the performance of selected trees in progeny tests and their respective clones in the clonal test. Reducing the selection intensity of the trees in progeny tests is an alternative to improve the efficiency of clonal test in the future.

\section{Acknowledgements}

The authors thank the Fibria Celulose S.A. company for the data given for this study and the Conselho Nacional de Desenvolvimento Científico e Tecnológico (CNPq), for a scholarship and research grant; Dr. MARCOS DEON Vilela DE REsende and Dr. José AiRToN RODRIGUES NUNES for their help in statistical analyses of the data.

\section{References}

Assis, T. F. (2000): Production and use of Eucalyptus hybrids for industrial purposes. Proceedings of Hybrid Breeding and Genetics of Forest Trees, Department of Primary Industries, Noosa, p. 63-74.

BERNARDO, R. (2002): Breeding for Quantitative Traits in Plants. Woodbury, Minnesota.

Bertolucci, F. DE L. G., G. D. S. P. Rezende and R. PANCHEL (1995): Produção e utilização de híbridos de eucalipto. Silvicultura 26: $12-16$.

Bouvet, J. M., A. SAyA and P. H. Vigneron (2009): Trends in additive, dominance and environmental effects with age for growth traits in Eucalyptus hybrid populations. Euphytica 165: 35-54.

FenR, W. R. (1987): Principles of Cultivar Development. Macmillan, Iowa.

FerReira, M. and P. E. T. SANTos (1997): Melhoramento genético florestal dos Eucalyptus no Brasil - breve histórico e perspectivas. Proceedings of Conference on Silviculture and Improvement of Eucalypt, IUFRO, Salvador, p. 14-34.

Freitas, R. G., E. S. Vasconcelos, C. D. Cruz, A. M. RosaDO, R. B. RochA and L. K. TAKAMI (2009): Predição de ganhos genéticos em progênies de polinização aberta de Eucalyptus urograndis cultivadas em diferentes ambientes e submetidas a diferentes procedimentos de seleção. Revista Árvore 33: 255-263.

FREY, K. J. and T. HORNER (1957): Heritability in standard units. Agronomy Journal 49: 59-62.

Gonçalves, F., G. D. S. P. Rezende, F. L. G. Bertolucci, M. A. P. Ramalho (2001): Progresso genético por meio de seleção de clones de eucalipto em plantios comerciais. Revista Árvore 25: 295-301.

Hallauer, A. R., M. J. Carena and J. B. Miranda Filho (2010): Quantitative Genetics in Maize Breeding. Iowa State University, Ames.

HAMBlin, J. E. and M. J. DE O. ZimMERMANN (1986): Breeding common bean for yield in mixtures. Plant Breeding Reviews 4: 245-272.

Mendes, F. F., M. A. P. RAMALHO and A. de F. B. ABREU (2009): Índice de seleção para escolha de populações segregantes de feijoeiro-comum. Pesquisa Agropecuária Brasileira 44: 1312-1318.

Nunes, J. A. R., A. L. Moreto and M. A. P. Ramalho (2008): Using genealogy to improve selection efficiency of pedigree method. Scientia Agrícola 65: 25-30.

Piepho, H. P., J. Mohring, A. E. Melchinger and A. Buchse (2008): BLUP for phenotypic selection in plant breeding and variety testing. Euphytica 161: 209-228.

Reis, C. A. F., F. M. A. Gonçalves, L. N. Rosse, R. R. G. F. Costa and M. A. P. Ramalho (2011): Correspondence between performance of Eucalyptus spp trees selected from family and clonal tests. Genetics and Molecular Research 10: 1172-1179.

Resende, M. D. V. DE and J. B. Duarte (2007): Precisão e controle de qualidade em experimentos de avaliação de cultivares. Pesquisa Agropecuária Tropical 37: 182-194.

Resende, M. D. V. DE. (2002): Genética Biométrica e Estatística no Melhoramento de Plantas Perenes. EMBRAPA Informação Tecnológica, Brasília.

RESENDE, M. D. V. DE. (2007): Software Selegen REML/BLUP: Sistema Estatístico e Seleção Genética Computadorizada via Modelos Mistos. EMBRAPA Florestas, Colombo.

Rezende, G. D. S. P. and M. D. V. Resende (2000): Dominance effects in Eucalyptus grandis, Eucalyptus urophylla and hybrids. Proceedings of Hybrid Breeding and Genetics of Forest Trees, Department of Primary Industries, Noosa, p. 93-100.

Rezende, G. D. S. P (2001): Melhoramento genético do eucalipto. Anais do Congresso Brasileiro de Melhoramento de Plantas, EMBRAPA Arroz e Feijão, Goiânia (1 CD-ROM).

Rosado, A. M., T. B. Rosado, M. F. R. Resende Júnior, L. L. Bhering and C. D. CRUZ (2009): Ganhos genéticos preditos por diferentes métodos de seleção em progênies de Eucalyptus urophylla. Pesquisa Agropecuária Brasileira 44: 1653-1659.

Statistical ANAlysis System Institute (2002): SAS: User's Guide Statistical (version 9) ed. Cary, NC.

Scarpinati, E. A., D. Perecin, R. C. Paula, C. A. V. BoniNE, B. E. PAVAN and L. S. CANDIDo (2009): Influência do modelo de análise estatística e da forma das parcelas experimentais na seleção de clones de Eucalyptus spp. Revista Árvore 33: 69-776.

VERRYN, S. D. (2000): Eucalyptus hybrid breeding in South Africa. Proceedings of Hybrid Breeding and Genetics of Forest Trees, 2000, Department of Primary Industries, Noosa, p. 191-199. 